\title{
TECHNO-PEST CONTROL BERBASIS IOT UNTUK PROTEKSI TANAMAN PADI
}

\author{
Dianna Ratnawati ${ }^{1}$, Bayu Rahmat Setiadi ${ }^{2}$ \\ ${ }^{1}$ Pendidikan Teknik Mesin Universitas Sarjanawiyata Tamansiswa; ${ }^{2}$ Jurusan Pendidikan Teknik Mesin, Universitas Negeri \\ Yogyakarta \\ Email: dianna.ratnawati@ustjogja.ac.id
}

\begin{abstract}
Pest insects such as planthoppers and grasshoppers cannot be eradicated using pesticides. The objectives of this research are: (1) to produce a techno-pest control to repel or to exterminate planthopper and grasshopper pests; (2) to find out the impact of the use of said techno-pest control in controlling planthopper and grasshopper pests. The research methods being used is an experiment with a test-device at a distance of three and six meters. The technology being developed is based on Internet of Things (IoT) which is set at a frequency of $40 \mathrm{kHz}$ and is controlled via a smartphone. This technology is equipped with an IP camera to monitor the condition of the rice fields. The result of the trial at a distance of 3 meters could kill planthoppers and grasshoppers within 8 hours. Whereas at a distance of $6 \mathrm{~m}$ it was able to kill planthoppers and grasshoppers within 13 hours. At the early stage, the insect pests showed a silent reaction because their metabolism was disrupted by the sound effects released by the device, before the pests died. It can be concluded that techno-pest control is suitable to be used as an environmentally friendly technology to protect rice field from planthoppers and grasshoppers.
\end{abstract}

Keywords: grasshoppers, iot, pest control, planthoppers, rice

\begin{abstract}
ABSTRAK
Hama wereng dan belalang yang menyerang tanaman padi tidak mampu dimusnahkan dengan pertisida. Tujuan penelitian ini : (1) menghasilkan techno-pest control untuk mengusir/membasmi hama wereng dan belalang; (2) mengetahui dampak penggunaan techno-pest control dalam pengendalian hama wereng dan belalang. Metode yang digunakan adalah eksperimen dengan uji coba alat pada jarak $3 \mathrm{~m}$ dan $6 \mathrm{~m}$. Teknologi yang dihasilkan berbasis IoT yang disetting pada frekuensi $40 \mathrm{kHz}$ dan dikontrol melalui smartphone. Teknologi ini dilengkapi dengan IP camera sebagai monitoring kondisi sawah. Hasil uji coba pada jarak $3 \mathrm{~m}$ mampu membunuh wereng dan belalang dalam waktu 8 jam. Sedangkan pada jarak $6 \mathrm{~m}$ mampu membunuh wereng dan belalang dalam waktu 13 jam. Pada tahap awal hama menunjukkan reaksi diam karena metabolisme terganggu dengan efek suara yang dikeluarkan alat hingga hama mati. Sehingga dapat kesimpulan bahwa techno-pest control layak digunakan sebagai teknologi proteksi tanaman padi dari hama wereng dan belalang yang ramah lingkungan.
\end{abstract}

Kata kunci: wereng, belalang, IoT, padi

\section{PENDAHULUAN}

Padukuhan Pondok yang terletak di kecamatan Depok, Kabupaten Sleman DIY berpotensi tinggi sebagai wilayah agraris penghasil swasembada padi. Mata pencaharian mayoritas penduduk adalah petani dengan ketersediaan hamparan sawah yang masih terbentang luas di area padukuhan. Pada bulan Maret 2019 berdasarkan hasil survey dilokasi pondok, para petani mengeluhkan produksi padi yang menurun dikarenakan selain faktor curah hujan yang berkepanjangan juga disebabkan oleh musuh abadi yang susah dikendalikan yaitu meledaknya populasi hama baik wereng maupun belalang. Hal senada ditegaskan dari data statistik Ida (1979:360) pada musim penghujan di Asia yaitu bulan Maret hingga April perkembangbiakan populasi wereng coklat mengalami kenaikan signifikan. Menurut Manueke dkk (2017:120-127) hama wereng menyerang pada fase vegetatif, menghisap 
cairan batang padi, dapat menularkan virus tungro dan virus kerdil, gejala terparahnya hopperburn yang akan menyebabkan puso atau gagal total. Sedangkan hama belalang menyerang pada fase generatif yang menghisap cairan pada bulir padi yang menyebabkan bulir padi hampa/tidak penuh dan terjadi grain discoloration. Beragam upaya telah dilakukan petani dengan melakukan penyemprotan pertisida pagi dan sore secara serempak diarea persawahan. Namun, populasi ini tetap dapat berkembang dengan pesat, hama berpindah dari area sawah lain tanpa bisa dikendalikan. Penyemprotan pertisida berulangkali dengan dosis yang lebih tinggi justru menjadikan resistensi pada hama, sehingga keberadaan hama semakin sulit dibasmi. Disamping itu, efek paparan pestisida bersifat polutan dan mengakibatkan radikal bebas yang dapat menyebabkan kerusakan organ (cacat, kerusakan syaraf, mutasi genetik), meracuni lewat kulit dan pernapasan, menimbulkan pencemaran udara, dan pencemaran air tanah karena kontaminan yang dapat berdampak terjangkitnya penyakit (Adiba, 2015:134-143). Kurangnya antisipasi memberikan dampak negatif dari warga, maka perlu diedukasi dan dicarikan alternatif teknologi tepat guna yang lebih safety dan akreditable untuk mengusir hama. Jongga (2012) upaya pengendalian populasi hama belalang dapat dilakukan dengan gelombang bunyi ultrasonik > $20 \mathrm{kHz}$ untuk mengacaukan komunikasinya, menghambat perkembangbiakan, mengacaukan pola reaksi gerak dan membubarkan dari komunitasnya. Lebih lanjut Rian (2012: 11-24) menjelaskan frekuensi yang dapat mengacaukan komunikasi hama wereng adalah $\geq 40 \mathrm{kHz}$, dimana pada frekuensi tersebut mampu menimbulkan reaksi gerak pasif hingga hama mati.

Melihat fasilitas yang dimiliki petani di Padukuhan Pondok berupa smartphone maka relevan dijadikan media pendukung untuk alat pengusir hama wereng maupun belalang. Penelelitian ini bertujuan untuk (1) menghasilkan alat teknologi tepat guna yaitu techno-pest control berbasis IoT untuk mengusir dan membunuh hama wereng dan belalang; dan (2) mengetahui dampak dari penggunaan alat techno-pest control dalam mengendalikan hama wereng dan belalang pada tanaman padi.

\section{METODE}

Metode Penelitian ini menghasilkan alat techno-pest control berbasis IoT yang akan diujicobakan pada jarak $3 \mathrm{~m}$ dan $6 \mathrm{~m}$ dengan objek sasaran wereng dan belalang. Tahapan dalam penelitian diawali dengan pembuatan alat, uji coba alat, revisi alat hingga didapatkan produk final. Sedangkan alur kerja techno-pest control dapat dilihat pada Gambar 1 dan Gambar 2 berikut.

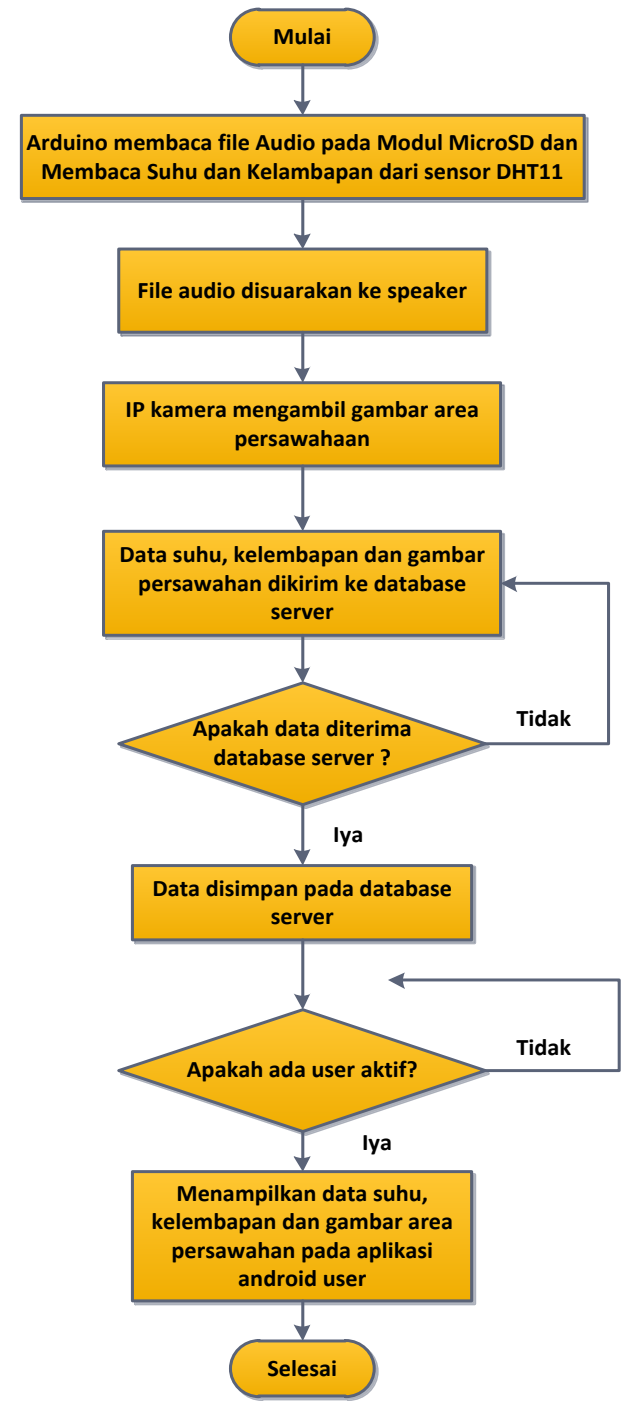

Gambar 1. Flowchat sistem kerja techno-pest control 


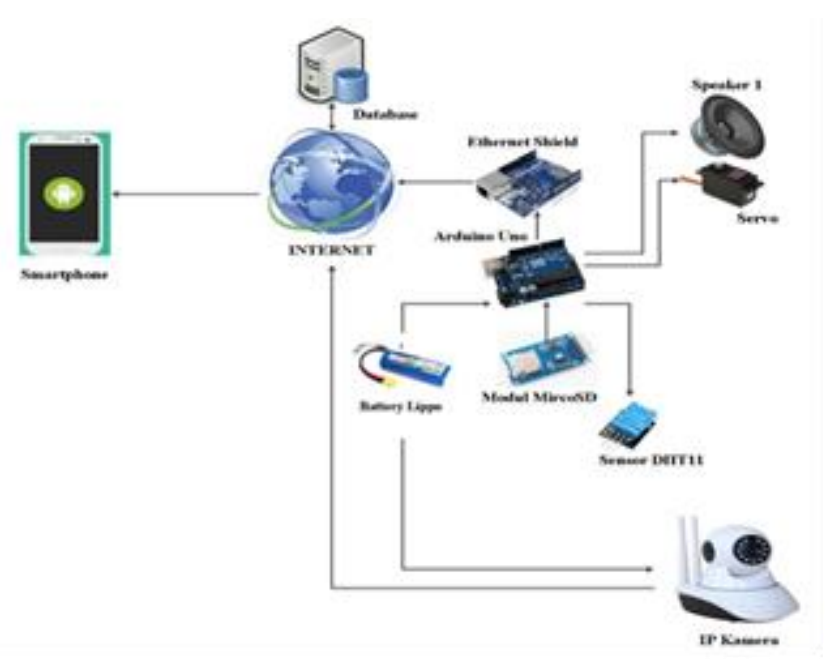

Gambar 2. Diagram Blok Sistem

Sistem ini dimulai dengan membaca audio yang telah disiapkan pada modul MircoSD. Aaudio digunakan untuk menghilangkan hama wereng dan belalang yang akan disuarakan melalui speaker. Speaker diintegrasikan dengan motor servo. Motor servo digunakan untuk menggerakan speaker agar speaker dapat bergerak berputar hingga $180^{\circ}$. Selanjutnya sistem akan membaca suhu dan kelembaban dari sensor DHT11. Sensor DHT11 digunakan untuk mengetahui kondisi suhu dan kelembaban diarea persawahan. Data dari sensor DHT11 dikirim ke database server melalui Ethernet Shield yang terhubung dengan jaringan Internet. Untuk mengetahui keadaan dari area persawahan digunakan IP kamera. IP Kamera mengambil gambar area persawahan dan data gambar akan disimpan di database server. Aplikasi yang didesain berbasiskan Android dapat diaksis pada laman "systecho.xyz". Aplikasi ini akan menampilkan data suhu dan kelembaban serta gambar area persawahan. Semua data dari database akan langsung tampil pada smartphone.

\section{HASIL DAN PEMBAHASAN}

Produk yang dihasilkan dapat dilihat pada Gambar 3.

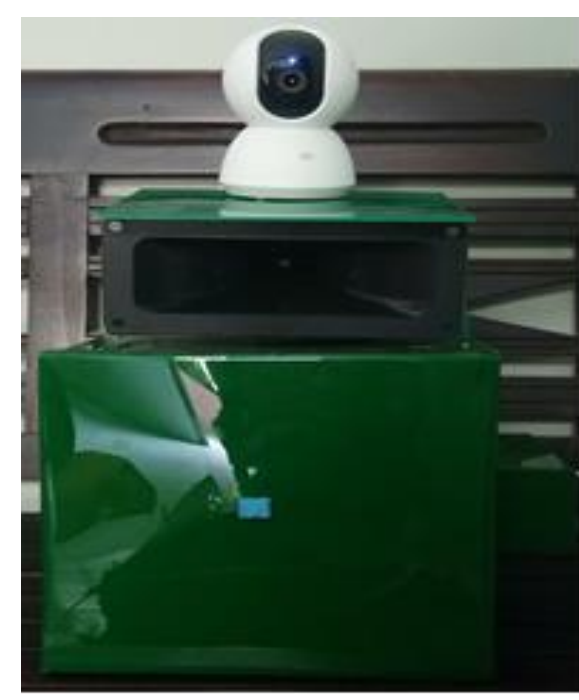

Gambar 3. Techno-pest control

Prosedur pengoperasian alat ini dimulai dengan menyalakan saklar (on). Secara otomatis speaker akan mengeluarkan suara. Volume suara yang dihasilkan dapat setting dari remote control. Selanjutnya koneksikan dengan wifi agar servo dapat berputar $180^{\circ}$ sehingga frekuensi yang dikeluarkan dapat berotasi. Setelah alat bekerja, sensor DHT11 mendeteksi suhu dan kelembaban dilingkungan sekitar. Sedangkan IP camera akan mengirimkan gambar kondisi sawah. Akses data baik suhu, kelembaban dan gambar dapat dilihat di "systecho.xyz" pada smartphone android. Data akan dikirim ke sistem tiap 1 jam sekali. Jika hama wereng dan belalang sudah tidak ada, alat dapat dimatikan dengan mematikan saklar (off) dan mematikan wifi.

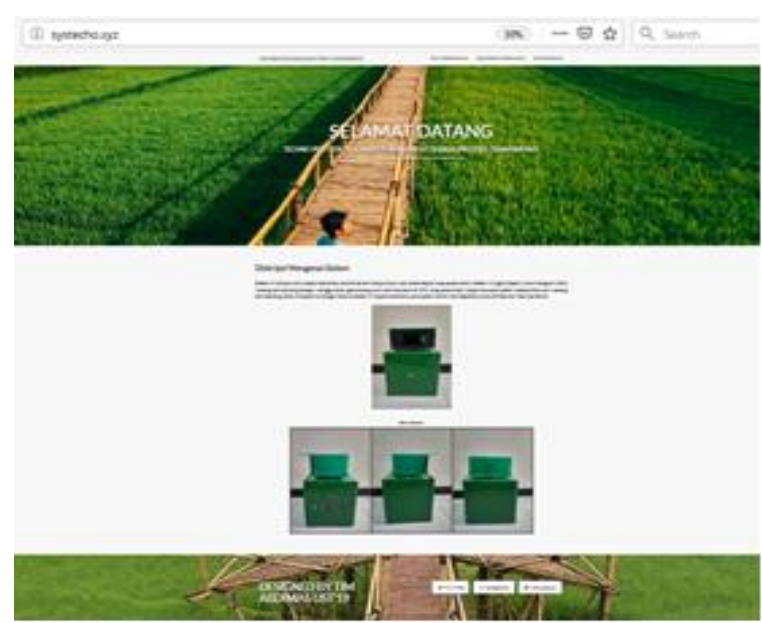

Gambar 4. Sistem web techno-pest control berbasis IoT 
Pada sistem web yang tertera pada Gambar 4. Menampilkan pilihan menu suhu, kelembaban dan kondisi sawah. Masing-masing menu menampilkan data sesuai kondisi lingkungan sekitar/area sawah.

Alat techno-pest control diuji cobakan pada hama wereng dan belalang dengan masing-masing hama dipilih 5 sampel. Jarak antara alat dengan hama dikondisikan pada radius 3 meter dan 6 meter. Pada hama wereng membutuhkan waktu 8 jam untuk membunuh hama dan 13 jam untuk jarak 6 meter. sebelum hama mati, reaksi yang ditunjukkan yaitu kondisi pasif. Demikian halnya untuk hama belalang, pada jarak 3 meter membutuhkan waktu 7.45 menit $/ 7 \frac{3}{4}$ jam mampu membunuh hama. Sedangkan pada jarak 6 meter membutuhkan waktu 12.30 menit/12 $\frac{1}{2}$ jam untuk membunuh hama. Sehingga rata-rata waktu yang dibutuhkan

Data ini dapat dilihat pada Tabel 1. Dengan demikian jika hama dalam kondisi bebas (menempel pada tanaman padi di sawah) saat alat difungsikan dapat mengusir hama pada menit awal atau hama diam pada tanaman tidak memakan tanaman padi dan dapat membunuhnya sesuai data yang ditampilkan pada Tabel 1.

Tabel 1. Hasil uji coba alat

\begin{tabular}{cccc}
\hline Sampel & Jarak & Waktu & Hasil \\
\hline Wereng & $3 \mathrm{~m}$ & 8 jam & hama mati \\
& $6 \mathrm{~m}$ & $13 \mathrm{jam}$ & hama mati \\
Belalang & $3 \mathrm{~m}$ & $7 \frac{3}{4} \mathrm{jam}$ & hama mati \\
& & $12 \frac{1}{2} \mathrm{jam}$ & hama mati \\
& $6 \mathrm{~m}$ & &
\end{tabular}

Wereng dan belalang termasuk dalam satu kelas insecta. Stepanus (2004) menegaskan bahwa insecta pada umumnya menggunakan gelombang ultrasonik untuk berkomunikasi dalam rentang frekuensi 20
kHz sampai $60 \mathrm{kHz}$. Maka dengan alat technopest control yang mampu menghasilkan suara dengan frekuensi $40 \mathrm{kHz}$ mengakibatkan komunikasi antar insecta akan terganggu sehingga tidak mampu mengumpulkan hama lain untuk berkumpul membentuk komunitas untuk memakan tanaman padi. Dengan kata lain populasi hama dapat dikendalikan. Rian (2012: 11-24) menegaskan frekuensi yang dapat mengacaukan komunikasi hama wereng adalah $\geq 40 \mathrm{kHz}$, mampu menimbulkan reaksi gerak pasif hingga hama mati. Dengan demikian techno-pest control ini sesuai dijadikan alat untuk pengusir sekaligus pembasmi hama wereng dan belalang. Terbukti dengan data yang ditampilkan pada Tabel 1. Semua hama baik wereng maupun belalang mati.
$\triangle \quad$ (i) systecho.xyz
(D) :

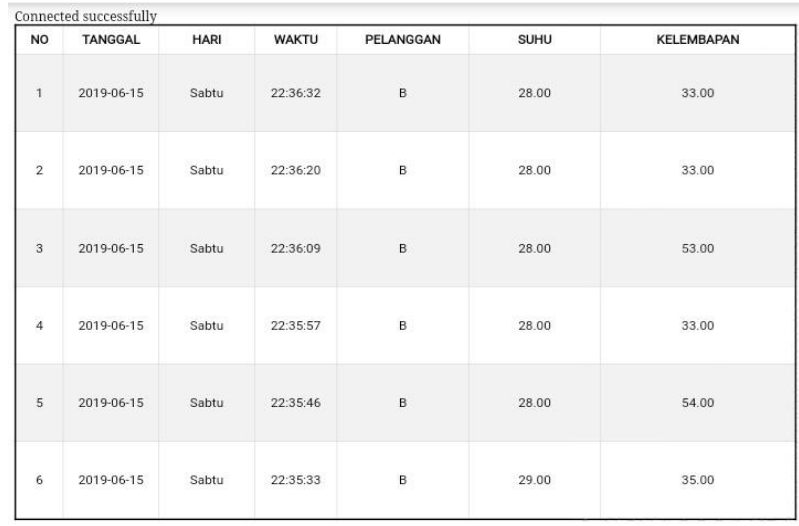

Gambar 5. Data suhu dan kelembaban di sawah

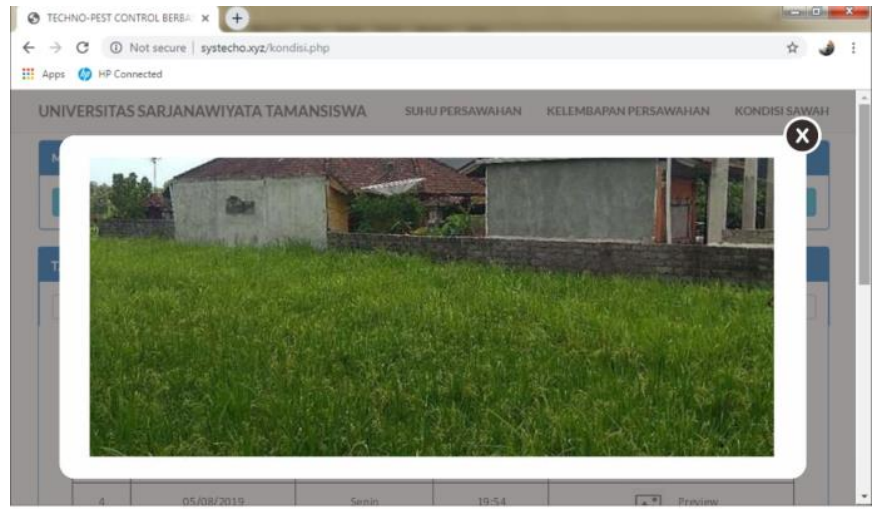

Gambar 6. Kondisi sawah di Padukuhan Pondok, Sleman

Pada kondisi dingin dan kelembaban tinggi, dimana hama insecta baik wereng dan belelang 
ada pada fase perkembangbiakan pesat, kondisi sawah masih aman, belum nampak gejala daun kecoklatan dan tidak nampak biji padi puso. Dengan demikian alat techno-pest control berbasis IoT ini mampu mengendalikan serangan hama wereng dan belalang.

\section{SIMPULAN}

Techno-pest control berbasis IoT layak digunakan untuk petani padi sebagai teknologi tepat guna pengganti pestisida yang mampu mengusir/membunuh hama wereng dan belalang lebih efektif dan ramah lingkungan.

\section{DAFTAR RUJUKAN}

Adiba, Arif. 2015. Pengaruh Bahan Kimia Terhadap Penggunaan Pestisida Lingkungan. JF FIK UINAM, 3(4). Hal. 134-143.

Ida, Nyoman Oka. 1979. Cultural Control of The Brown Planthpper. Bogor: Central Research Institute for Agriculture. pp 360 .
Manueke, Jusuf, Assa, Berty H., Pelealu, Evangeline A. 2017. Hama-Hama Pada Tanaman Padi Sawah (Oryza Sativa L.) Di Kelurahan Makalonsow Kecamatan Tondano Timur Kabupaten Minahasa. Jurnal Eugenia, 23(3). Hal. 120-127.

Jongga, Manullang. 2012. Pengaruh Frekuensi Ultrasonik Terhadap Pola Perilaku Belalang Kumbara Sebagai Pengendali Hama Secara Elektronik. Jurnal Generasi Kampus, 5(1).

Rian, Agusdian. 2012. Sistem Proteksi Tanaman Padi Dari Serangan Hama Wereng Menggunakan Gelombang Ultrasonik Dan Penunjuk Arah Angin. Prosiding: Seminar Nasional Fisika dan Pendidikan Fisika, Pendidikan Karakter dalam Perspektif Sains dan Religi, Surakarta, 15 September 2012, 3(1). Hal 11- 24.

Stepanus.2004. Gelombang Ultrasonik sebagai Pengendali Hama Belalang. Yogyakarta: Graha Ilmu 